\title{
An Application Guide for Compulsators
}

\author{
Jon R. KITZMILLER, Siddarth B. PRATAP and Mircea D. DRIGA
}

\begin{abstract}
Focus towards advanced mobile tactical configurations for railgun power supplies has resulted in the evolution of five compulsator generations in the past fifteen years. Unfortunately, the rapid maturation of the technology has tended to dilute the relative importance and application base of previous generations. Technical variance between generations has been significant including air-core or iron-core, rotating armature or field, single or multi-phase, solid rotor or shell, and externally excited or self-excited. It is useful, therefore, to review and classify the important distinctions between the generations of machines thus allowing proper selection of the one best suited for a given application.

This paper provides an overview of the evolution of compulsators developed at The University of Texas at Austin Center for Electromechanics. Features of past and present configurations are discussed, such as machine topology, method of excitation, basic switching methods, discharge pulse shapes, and potential energy and power densities. A list of potential applications is generated for all disciplines within the armed forces. This information is used to create an application guide that can be used to select appropriate compulsator options for the mission given. An extensive list of references is also provided.
\end{abstract}

\section{INTRODUCTION}

A $\mathrm{T}$ The University of Texas at Austin Center for Electromechanics (UT-CEM), compulsator (CPA) technology was first demonstrated as applicable to railguns with an ironcore CPA [1] that fired $80 \mathrm{~g}$ hybrid solid armatures at 2,000 $\mathrm{m} / \mathrm{s}$ down a pair of 30-mm railguns (Fig. 1). Delivering pulsed electric power at the $1 \mathrm{GW}$ level, this machine was the highest power density synchronous generator in existence at that time. This single phase, rotating field, iron core machine weighed over 12 U.S. tons and was literally orders of magnitude away from having what is estimated to be an acceptable delivered energy density (DED) for tactical applications. DED relates total energy input into the railgun with power supply system mass, and has played a large role in the rapid development of the CPA since 1985. Although completely successful, the iron-core CPA was the first and last of its generation, rendered obsolete by the development of advanced air-core platforms

Manuscript received January 11, 2002. A portion of this research was carried out under the Electric Gun Program sponsored by the U.S. Army Research Laboratory through Lockheed-Martin Missile and Fire Control under contract number 4300050944.

J.R. Kitzmiller and S.B. Pratap are affiliated with The University of Texas at Austin Center for Electromechanics, Austin, Texas 78758, (512) 471-4496, fax (512) 471-0781.

M.D. Driga is affiliated with The University of Texas at Austin Department of Electrical and Computer Engineering, Austin, Texas 78712, (512) 471-6179, fax (512) 471-3652. using lightweight structural composites. Since the success of the iron-core CPA, three newer generations of the CPA have been designed, built, and tested at UT-CEM, and another is currently under development.

Innovative features and benefits unique to the previous generation CPA have been eclipsed by the latest advanced DED machine. It does not follow, however, that the latest generation is the best choice for all applications. Fig. 2 shows a list of the configuration options used in all CPAs developed at UT-CEM. There may be only one set of configuration selections that meet a strict set of mission requirements (such as those which emphasize DED), but more than one viable combination may be suitable for more general missions.

\section{CPA OVERVIEW}

The CPA is a synchronous generator intentionally designed to maximize short circuit current output by minimizing internal impedance through the action of flux compression and/or aircore topology. Flux compression is achieved through the use of special internal windings (compensating windings) normally referred to in one of three classes as passive, selective passive, or active. In some cases there may be no compensating winding used, although the field winding mimics the function of a wound compensating winding itself and will compress flux between itself and the armature for parts of the discharge cycle.

One other design that has evolved is called the "uncompulsator." As opposed to the previous high current output designs, this machine was proposed as a very high voltage pulsed electric machine. This device works by short circuiting a part of the output from the machine which naturally induces high voltage on the remaining output branches. It is the opposite (electromagnetic dual) of a CPA in which not only is the compensating winding eliminated, but also all the other means of suppressing over-voltages are removed [2,3].

There are many things to consider when designing a CPA because of the many inherent variations (as the block diagram of Fig. 2 shows). Perhaps the most important decision to make is whether the machine is to be iron based or air-core. Knowing the mission requirements expedites this decision. In general, the iron-core machines are much more robust than their air-core cousins, at the expense of DED. However, the risk and expense in using the less efficient, air-core class machine forces careful consideration of the DED requirement. In general, if there are high ranking system mass and volume 
constraints, then one is quickly forced to consider air-core machinery. Other things worth noting about the CPA topology options of Fig. 2 follow.

Phases - Unlike conventional iron core machinery, CPA winding forces are developed almost exclusively within the conductors themselves. In multiphase machinery, phase-tophase commutation loads lead to the desire for four phases rather than three. The single-phase machine has a natural current zero and passive energy recovery from the railgun. There are still projectile issues related to the removal of current before it exits the gun, however. A multiphase system offers much more flexibility in current waveform shaping, and the use of a muzzle shunt may alleviate the problems associated with current removal prior to exit.

Rotating field or armature - Both have been tested successfully at UT-CEM. Brush duty and volume requirements usually lead toward selection of a rotating field.

Excitation - Iron-core designs may use either external excitation or self-excitation, as appropriate. Typical dc power requirement is 1,500 to 2,500 $\mathrm{A}$ at a few hundred volts. Aircore machines may have power requirements as much as 1,000 times those of the iron-core machine for charging efficiently, which mandates the use of self-excitation.

Energy reclamation - Magnetic energy can be reclaimed from the field coil and railgun. For iron-core applications, the field energy is low and energy reclamation is not generally warranted. Air-core design efficiency will suffer if the field energy is not reclaimed, however. Both topologies benefit from railgun energy reclamation. Reclamation from the railgun is passive when using a single-phase system.

Table 4 shows the configurations of five CPA generations developed at UT-CEM for electric gun applications, beginning with the iron core CPA. Photographs of the machines for generations one through four are seen in Figs. 1, 3, 4, and 5. The sharp rise in energy density has been brought about primarily in two areas, namely, composite materials and selfexcitation. In addition, the fielded compulsator will have to be cooled in order to support sustained mobile engagements. UTCEM is presently developing this cooling technology for the latest CPA generation.

Structural materials for the advanced machines are composite because of their very high specific strength and stiffness properties. The machines are inherently air-core, which has in turn led to the use of self-excitation to produce the extremely high internal flux such devices require. The reasoning for all of this is fairly simple. It is readily apparent that iron-core CPAs are not suitable for pushing the envelope of attainable DED, so composite topology is an obvious alternative. Air-core machines, however, require much more ( $>10 \mathrm{X}$ typically) excitation than their iron-core counterparts. Self-excitation is the solution to this problem. Because the CPA is inherently capable of very high power railgun current pulses, then it is also able to provide the much lower power requirement that even the air-core field demands. Also, since the iron is absent, the generator flux can be established much faster and efficiency issues can be addressed.

Generator cooling is also under development now to allow the use of the CPA beyond basic laboratory shot numbers. Although there is no shortage of modern cooled rotating machines, none come remotely close to operating at the speeds, stresses, and strains of an advanced air-core CPA. There is still much work to be done.

With this overview of CPA operations in mind, a designer may select a combination of CPA topologies to provide power supplies matched to the requirements of each mission scenario.

\section{COMPUlSATOR Missions AND THE APPLICATION GUIDE}

Primary emphasis of CPA power development currently resides within the U.S. Army as it relates to advanced applications within futuristic combat vehicles. However, other branches of the armed forces have also shown interest:

- small-caliber $[4,5]$ and cannon-caliber [6,7] systems, U.S. Marine Corps

- electric guns for larger platforms like the modern AC130 gunship [8], U.S. Air Force

- electric launch technology for future naval platforms [9], U.S. Navy

Table 1 is a compilation of potential missions for CPAs, listed according to the respective primary defensive disciplines. The table also lists applications for designs using electrothermal-chemical cartridge (ETC), laser, and the highvoltage uncompulsator.

There is certain similarity between the topologies required by different disciplines. For example, one could assume that the need for high DED is a requirement shared by the U.S. Air Force, U.S. Army, and U.S. Marines; however, this requirement may be less for the U.S. Navy with larger supportable masses and volumes aboard ships. Otherwise, the grouping of the CPAs into correct places within the application guide was done based largely upon the experience of the authors [6,10,11,12,13,14,15,16,17].

Table 2 summarizes the configuration options used in each of the applications listed in Table 1 (codes used in Table 2 are explained in Table 3). As can be seen, there are few easy answers when it comes to selecting the optimal CPA for a given mission. In general, many trades must still be analyzed within the CPA itself to arrive at the optimal design.

\section{Summary AND CONCLUSIONS}

Rapid development of the CPA over the years has led to the existence of many proven variations. Though present emphasis is on high DED, these new machines may not be the best selections for all applications. This is particularly true for naval applications, under the assumption that mass and volume constraints are much lessened compared to mobile armor and air force applications. The design guide presented can be a helpful tool for the electric gun technology planner, as it associates design features with general mission descriptions. It is critically important, however, to fully define and understand mission requirements, as this will drive the critical selection of 
air-core or iron-core topology. Finally, the design of the CPA will still require trades internal to the specific generator in order to define the optimal configuration.

\section{REFERENCES}

[1] M.D. Werst, "Testing of a Rapid Fire Compensated Pulsed Alternator System," Fourth EML, Austin, TX April 12-14, 1988.

[2] M.D. Driga, Final Report to the U.S. Army, Fort Belvoir RDE Center under contract DAAK-87-P-3597, December 1988.

[3] Rudolf Richter, Electrische Maschinen, Band II, Verlag Birkhauser, Basel-Stattgart, 1972, pp. 293-298.

[4] R.L. Fuller, J.R. Kitzmiller, S.B. Pratap, R.F. Thelen, "Salvo Fire Experiments Using a 0.60 Caliber Electromagnetic Launcher," 6th EML, IEEE Transmag, Vol 29, No 1, January 1993.

[5] R.N. Headifen, R.L. Fuller, J.R. Kitzmiller, "Commissioning of a High Speed Composite Rotor with Hydrostatic Dampers and Ceramic Rolling Element Bearings," 14th ASME Vibration and Noise Conference, Albuquerque, NM, September 19-23, 1993.

[6] J.R. Kitzmiller, R.F. Johnson, "Recent CCEMG Performance and System Implications for Future Electric Gun Development," AECV All Electric Combat Vehicle, June 9, 1997.

[7] J.R. Kitzmiller, S.B. Pratap, M.D. Werst, C.E. Penney, T.J. Hotz, B.T. Murphy, "Laboratory Testing of the Pulse Power System for the Cannon Caliber Electromagnetic Gun Systems (CCEMG)," 8th EML, IEEE Transmag, Vol 33, No 1, January 1997.

[8] M.L. Spann and G.E.Hauze, "An Investigation of the Feasibility of Incorporating Electromagnetic Gun Technology into an Airborne Tactical Weapons System," Task IV, Compulsator Phase I Final Report, Contract \#DAAK10-83-C-0126, December 1986.

[9] I.T. Luke, Jr., and M.F. Stumborg, "The Operational Value of Long Range Land Attack EM Guns to Future Naval Forces," 10th EML, IEEE Transmag, Part I, Vol 37, No. 1, pp 58-62.

[10] M.D. Driga, S.B. Pratap, and W.F. Weldon, "Design of Compensated Pulsed Alternators with Current Waveform Flexibility," Sixth IEEE Pulse Power Conference, Arlington VA, June 29-July1, 1987.

[11] M.D. Driga, S.B. Pratap, and W.F. Weldon, "Design of Advanced Compulsators," Fourth EML, Austin, TX, April 12-14, 1988.

[12] S.B. Pratap, M.D. Driga, W.F. Weldon, and M.L. Spann, "Future Trends for Compulsators Driving Railguns," Third Symposium on EML, Austin, TX, April 20-24, 1986.

[13] S.B. Pratap, K-T Hseih, M.D. Driga, and W.F. Weldon, "Advanced Compulsators for Railguns," Fourth EML, Austin, TX, April 12-14, 1988.

[14] W.A. Walls, M.L. Spann, S.B. Pratap, D.A.Bresie, W.G Brinkman, J.R. Kitzmiller, J.D. Herbst, H.-P. Liu, S.M. Manifold, and B.M. Rech, "Design of a Self-Excited, Air-Core Compulsator for a Skid Mounted, Repetitive Fire 9 MJ Railgun System," Fourth EML, Austin TX, April 12-14, 1988.

[15] M.L. Spann, S.B. Pratap, M.D. Werst, W.A. Walls, and W.G. Fulcher, "Compulsator Research at the University of Texas at Austin," 4th EML, IEEE Transmag, January 1989, Vol 25, No.1, April 12-14, pp 529-537.

[16] J.R. Kitzmiller et.al., "Predicted vs. Actual Performance of a Model Scale Compulsator System," 10th EML, IEEE Transmag, Vol 33, No 1, January 1999.

[17] J.R. Kitzmiller, J.A. Pappas, S.B. Pratap, M.D. Driga, "Single and Multiphase Compulsator System Architectures: A Practical Comparison," 10th EML, IEEE Transmag, Vol 33, No 1, January 1999.

[18] W.F. Weldon, M.D. Driga, W.L. Bird, K.M. Tolk, H.H. Woodson, and H.G. Rylander, "Compulsator -- A High Power Compensated Pulsed Alternator," Second International Conference on Energy Storage, Compression, and Switching, Venice, Italy, December 5-8, 1978.

[19] U.S. Patent No. 4,200,831, April 29, 1980, "Compensated Pulsed Alternator," W.F. Weldon, M.D. Driga, and H.H. Woodson

[20] W.G. Fulcher, R.W. Faidley, M.W. Ingram, S.B. Pratap, and M.L. Spann, "Design Considerations in a 60 caliber EM Railgun System," Fourth EML, Austin, TX, April 12-14 1988.

[21] J.R. Kitzmiller, "Final Design of an Air Core Compulsator Driven 60 Caliber Railgun System," 5th EML Symposium, San Destin, FL, April 3-5, 1990.
[22] M.D. Werst, J.R. Kitzmiller, A.E. Zielinski, "Rapid Fire Railgun for the Cannon Caliber Electromagnetic Gun System," 10th IEEE Pulse Power Conference, July 10-13, 1995.

[23] J.A. Pappas, D. Piccone, "Power Converters for Rail Guns," 10th EML, IEEE Transmag, Vol 33, No 1, January 1999.

[24] J.H. Gully, M.L. Spann, and S.B. Pratap, "Power Systems for Electrothermal Guns," Presented at the 26th JANNAF Combustion Meeting, Jet Propulsion Laboratory, Pasadena, CA, October 23-27, 1989.

[25] W.F. Weldon, M.D. Driga, "Concept Definition and Preliminary Design of a Limited Duty Power Supply Components -- Alternative Concepts," Response to Proposal DAAK70-87-Q-1034, U.S. Army Belvoir RD\&E Center, Fort Belvoir, VA, August 6, 1987. 
TABLE 1

DEFENSIVE APPLICATION AREAS FOR CPA-DRIVEN ELECTRIC GUNS

\begin{tabular}{|c|c|c|}
\hline Discipline & $\begin{array}{l}\text { Ref } \\
\#\end{array}$ & Mission Description \\
\hline \multirow[t]{5}{*}{ Army } & 1 & $\begin{array}{l}\text { Advanced armor; cannon caliber } \\
\text { mobile platforms }\end{array}$ \\
\hline & 2 & $\begin{array}{l}\text { Advanced armor; large bore mobile } \\
\text { platforms }\end{array}$ \\
\hline & 3 & Artillery, medium and long range \\
\hline & 4 & Missile defense \\
\hline & 5 & Anti-aircraft defense \\
\hline Marines & 6 & $\begin{array}{l}\text { Anti-armor; cannon caliber and large } \\
\text { bore amphibious mobile platform }\end{array}$ \\
\hline \multirow[t]{5}{*}{ Navy } & 7 & Artillery, medium and long range \\
\hline & 8 & Gun launched missile \\
\hline & 9 & Missile launch \\
\hline & 10 & Missile defense \\
\hline & 11 & Anti-aircraft defense \\
\hline \multirow[t]{2}{*}{ Air Force } & 12 & $\begin{array}{l}\text { Cannon and large caliber systems } \\
\text { for gunship platforms }\end{array}$ \\
\hline & 13 & Drone aircraft launch \\
\hline ETC & & $\begin{array}{l}\text { ETC guns power supplies, cannon } \\
\text { and large caliber }\end{array}$ \\
\hline LASER & & Beam and particle type weapons \\
\hline Uncompulsator & & $\begin{array}{l}\text { Limited EMP generator, } \\
\text { signal jammer }\end{array}$ \\
\hline
\end{tabular}

TABLE 2

APPLICATION DESIGN GUIDE FOR COMPULSATORS

\begin{tabular}{|c|c|c|c|c|c|c|c|c|c|c|c|c|c|c|c|c|}
\hline \multicolumn{17}{|c|}{ Application Reference } \\
\hline CPA Designation & 1 & 2 & 3 & 4 & 5 & 6 & 7 & 8 & 9 & 10 & 11 & 12 & 13 & $E^{\star}$ & $L^{*}$ & $U^{*}$ \\
\hline Topology & A & A & $\begin{array}{l}\text { A } \\
\text { I }\end{array}$ & $\begin{array}{c}A \\
1\end{array}$ & A & A & 1 & $\begin{array}{l}\text { A } \\
\text { I }\end{array}$ & 1 & $\begin{array}{l}\text { A } \\
\text { I }\end{array}$ & A & A & $\begin{array}{c}\text { A } \\
1\end{array}$ & $\begin{array}{c}A \\
1\end{array}$ & $\begin{array}{c}A \\
1\end{array}$ & $\begin{array}{l}\text { A } \\
\text { I }\end{array}$ \\
\hline Number of Phases & $\begin{array}{l}1 \\
4 \\
\end{array}$ & 4 & 4 & 4 & 1 & 1 & 4 & 4 & 4 & 4 & 4 & 1 & $\begin{array}{l}1 \\
4\end{array}$ & $\begin{array}{l}1 \\
4\end{array}$ & $\begin{array}{l}1 \\
4\end{array}$ & 4 \\
\hline Compensation & $\begin{array}{l}\text { SP } \\
\mathrm{N}\end{array}$ & $P$ & $\begin{array}{c}\mathrm{P} \\
\mathrm{SP} \\
\mathrm{N}\end{array}$ & $\begin{array}{c}\mathrm{P} \\
\mathrm{SP} \\
\mathrm{N} \\
\end{array}$ & \begin{tabular}{|c}
$\mathrm{P}$ \\
$\mathrm{SP}$ \\
$\mathrm{N}$
\end{tabular} & $\mathrm{N}$ & $P$ & $\mathrm{P}$ & $\mathrm{P}$ & $\mathrm{P}$ & $\mathrm{N}$ & $\mathrm{N}$ & $\mathrm{P}$ & SP & V & $\begin{array}{l}\text { SP } \\
\mathrm{N}\end{array}$ \\
\hline Rotating & $\begin{array}{c}F \\
A W\end{array}$ & $\mathrm{~F}$ & $\mathrm{~F}$ & $\mathrm{~F}$ & $\mathrm{~F}$ & $\mathrm{~F}$ & $\mathrm{~F}$ & $\mathrm{~F}$ & $\mathrm{~F}$ & $\mathrm{~F}$ & $\mathrm{~F}$ & $\mathrm{~F}$ & $\begin{array}{c}F \\
A W\end{array}$ & $\begin{array}{c}F \\
A W\end{array}$ & $\mathrm{~F}$ & $\mathrm{~F}$ \\
\hline Excitation & $\begin{array}{l}\mathrm{S} \\
\mathrm{E}\end{array}$ & $\begin{array}{l}\mathrm{S} \\
\mathrm{E}\end{array}$ & $\begin{array}{l}S \\
E\end{array}$ & $\begin{array}{l}\mathrm{S} \\
\mathrm{E}\end{array}$ & $\begin{array}{l}\mathrm{S} \\
\mathrm{E}\end{array}$ & $\begin{array}{l}\mathrm{S} \\
\mathrm{E}\end{array}$ & $E$ & $\begin{array}{l}\mathrm{S} \\
\mathrm{E}\end{array}$ & E & $E$ & $\mathrm{~S}$ & S & $E$ & $E$ & $\mathrm{E}$ & $\mathrm{S}$ \\
\hline Energy Recovery & B & B & $\begin{array}{l}\mathrm{B} \\
\mathrm{O}\end{array}$ & $\begin{array}{l}\mathrm{B} \\
\mathrm{O}\end{array}$ & $\begin{array}{l}\mathrm{B} \\
\mathrm{O}\end{array}$ & B & $\mathrm{O}$ & $\mathrm{O}$ & $\mathrm{O}$ & $\mathrm{O}$ & B & $B$ & $\mathrm{O}$ & $\mathrm{O}$ & $\mathrm{O}$ & $\mathrm{O}$ \\
\hline
\end{tabular}

${ }^{*} \mathrm{E}=\mathrm{ETC}, \mathrm{L}=$ laser, $\mathrm{U}=$ uncompulsator 
TABLE 3

CODE LEGEND FOR DESIGN GUIDE

\begin{tabular}{ll}
\hline \hline CPA Designation & \multicolumn{1}{c}{ Code Definition } \\
\hline Topology & $\mathrm{A}=$ Air-core \\
& $\mathrm{I}=$ Iron-core \\
Number of Phases & $1=$ Both (or either) \\
& $4=$ Fingle-phase \\
Compensation & $\mathrm{P}=$ Passive \\
& $\mathrm{SP}=$ Selective Passive \\
& $\mathrm{V}=$ Active \\
Rotating & $\mathrm{N}=$ None \\
& $\mathrm{F}=$ Field coil \\
Excitation & $\mathrm{AW}=$ Armature winding \\
& $\mathrm{S}=$ Self \\
Energy Recovery & $\mathrm{E}=$ Either self or external \\
& $\mathrm{B}=$ Both windings \\
\hline \hline
\end{tabular}

TABLE 4

EVOLUTION HISTORY OF THE CPA AT UT-CEM

\begin{tabular}{|c|c|}
\hline $\begin{array}{l}\text { GENERATION } 1 \\
\text { Iron Core CPA }\end{array}$ & $\begin{array}{l}\text { Single phase, iron core } \\
\text { Rotating field } \\
\text { 6-pole, passive compensation } \\
\text { Externally excited } \\
\text { Solid rotor }\end{array}$ \\
\hline $\begin{array}{l}\text { GENERATION } 2 \\
\text { Small Caliber } \\
\text { CPA }\end{array}$ & $\begin{array}{l}\text { Single phase, air core } \\
\text { Rotating dual armature } \\
\text { 2-pole, passive compensation } \\
\text { Self excited } \\
\text { Solid rotor }\end{array}$ \\
\hline $\begin{array}{l}\text { GENERATION } 3 \\
\text { Cannon Caliber } \\
\text { CPA (CCEMG) }\end{array}$ & $\begin{array}{l}\text { Single phase, air-core } \\
\text { Rotating armature } \\
\text { 4-pole, selective passive } \\
\text { Self excited } \\
\text { Solid rotor }\end{array}$ \\
\hline $\begin{array}{l}\text { GENERATION } 4 \\
\text { Subscale FTP }\end{array}$ & $\begin{array}{l}\text { Single phase, air-core } \\
\text { Rotating field } \\
\text { 6-pole uncompensated } \\
\text { Self excited } \\
\text { Hollow rotor }\end{array}$ \\
\hline $\begin{array}{l}\text { GENERATION } 5 \\
\text { Advanced FTP }\end{array}$ & $\begin{array}{l}\text { 4-phase, air core } \\
\text { Rotating field } \\
\text { 4-pole, uncompensated } \\
\text { Self excited } \\
\text { Advanced rim rotor }\end{array}$ \\
\hline
\end{tabular}

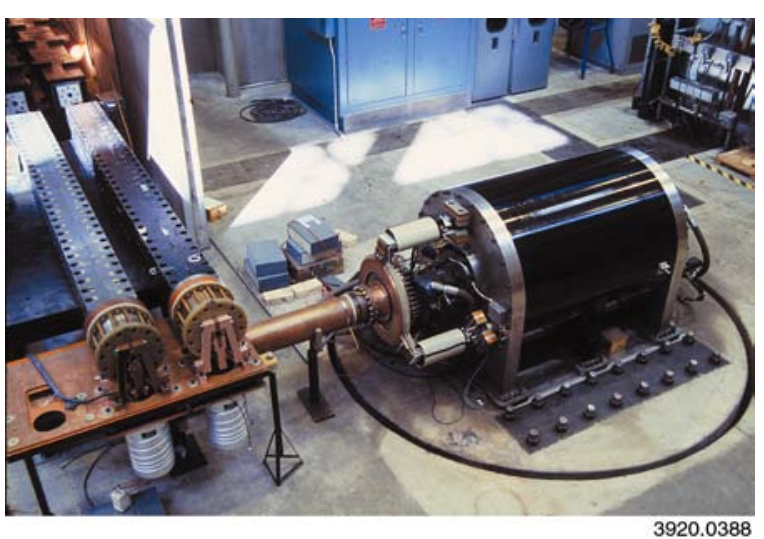

Figure 1. The iron-core compulsator at UT-CEM, 1986 (shown with twin $30 \mathrm{~mm}$ railguns)

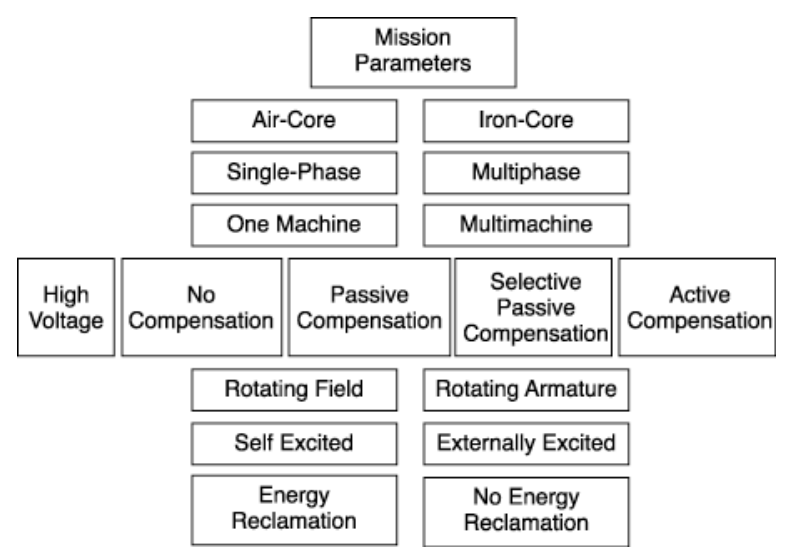

Figure 2. Options available for designing CPAs today; following careful outlay of the mission parameters, the blocks can be connected to provide a viable design

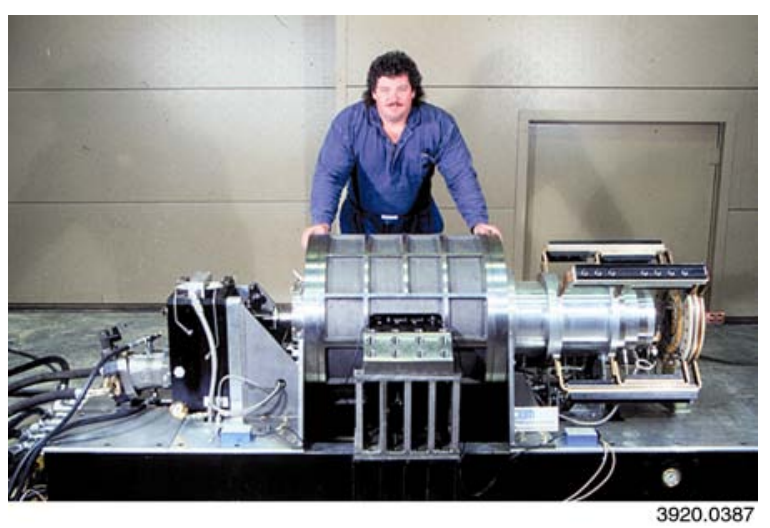

Figure 3. The small-caliber compulsator at UT-CEM, 1989 (pictured: J.R. Kitzmiller) 


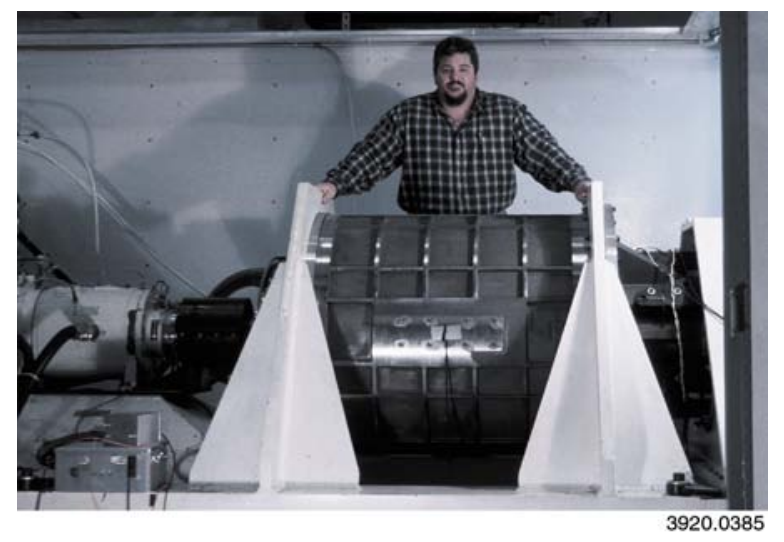

Figure 4. The cannon-caliber compulsator (CCEMG) at UT-CEM, 1992 (pictured: J.R. Kitzmiller)

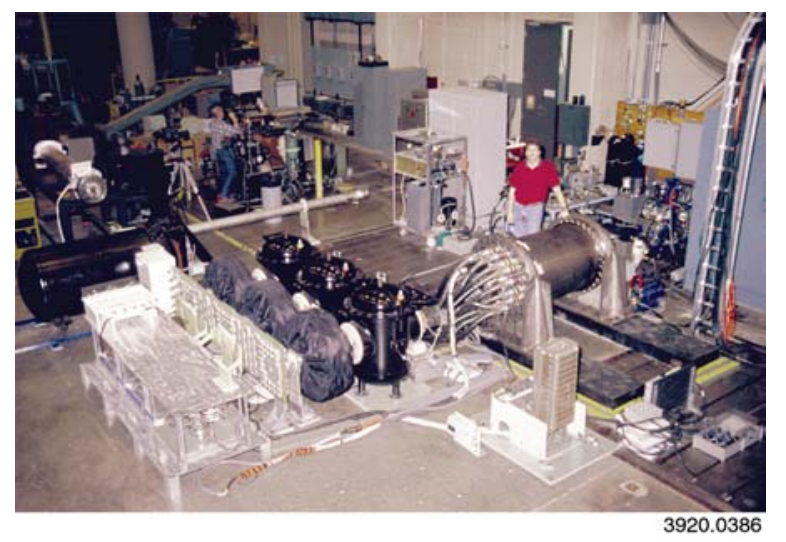

Figure 5. Subscale FTP compulsator system at UT-CEM, 1998 (pictured: J.J. Hahne) 